\title{
GIS-Forecasted Surface Hydrology for Reducing Risks of Food Production (Northern West Coast, Egypt)
}

\author{
Abd El-Hady A.M. ${ }^{1}$, Aggag A.M. ${ }^{2}$, Abdelaty E.F. ${ }^{3}$, Bahnassy M.H. ${ }^{4}$ \\ 1, 2, 3:Prof. , Assoc.Prof. and Lecturer, Dept. Natu. Res. \& Agric. Eng., Fac. Agric., \\ Damanhour Univ. 4:Prof. Soil\&Water, Fac.Agric.Alex.univ. (Egypt) \\ (www.damanhour.edu.eg) \\ Corresponding author: A.M. Abd El-Hady, hadyhady200@damanhour.edu.eg
}

\begin{abstract}
The North Western Coastal Region (NWCR) of Egypt is one of the most promising areas for agricultural development. It extends from Alexandria in the east to Sallum in the west with about $500 \mathrm{~km}$ width and $40 \mathrm{~km}$ depth. It located between longitude of $\left(29^{\circ} 50^{\prime} 00^{\prime \prime} \mathrm{E}\right.$ and $\left.25^{\circ} 10^{\prime} 00^{\prime \prime} \mathrm{E}\right)$ and latitude $\left(30^{\circ} 50^{\prime} 00^{\prime \prime} \mathrm{N}\right.$ and $\left.31^{\circ} 10^{\prime} 00^{\prime \prime} \mathrm{N}\right)$. The study area (El-Dabaa) covers an area of approximately 60490 hectare. It extends from $606259 \mathrm{E}$ to $651072 \mathrm{E}$ and from $3437982 \mathrm{~N}$ to $3416473 \mathrm{~N}$. The area is bounded on the north by the Alex-Matrouh road and on the south by Elgesh road.Four 1:50000 scaled-topographic maps covering the study area were digitized. The watersheds of El-Dabaa studied area that were derived from the digital elevation model (DEM) consist of fourteen basins having area ranged between $8.6 \mathrm{~km}^{2}$ to $136.8 \mathrm{~km}^{2}$. Stream networks showed twenty eight net outlets that localized the recommended twenty eight reservoirs of rain water. Flow accumulation map indicated that the studied region has large seven-flow accumulation that have the direction from south to north. The posted accumulated flow data were used to calculate the twenty eight reservoirs water capacity by being integrated with (a) slope gradient, (b) forecasted mean precipitation rate of the future climate period (2011-2030), and (c) surface runoff coefficient. The results referred the averaged harvested water may have a maximal (278828 $\mathrm{m}^{3} /$ year) and minimal values (18992 $\mathrm{m}^{3} /$ year). In addition, results indicated that the construction of these twenty eight water reservoirs may supply the population by $2604325 \mathrm{~m}^{3} /$ year for each year of the future period (2011-2030). Results of forecasted crops net irrigation water requirements of the future period (2011-2030), showed clearly that alfalfa needs largest one (1275 mm/year), while barley requires the smallest water requirements $(247 \mathrm{~mm} / \mathrm{season})$. Furthermore, sorghum and wheat net irrigation water requirements may be 330 and 250 ( $\mathrm{mm} /$ season), respectively.The compiling of forecasted net irrigation water requirements with that of harvested water reservoirs was conducted to calculate the total optional planting areas of the dominated crops. Alfalfa may be yearly planted over an area 6397.55 feddans. Other, optional planting areas may be 1535.93, 2027.42, and 2052.08 (feddans/season) for sorghum, wheat and barley, respectively. The number of cattle and sheep that can be grazed on irrigated harvested water-barley was calculated to assess land potential grazing capacity. Grazing capacity of the twenty eight locations has ranged between 75 to 1099 and 299 to 4396, for cattle and sheep, respectively. Grazing capacity has its min. and max.,surrounding reservoir no.26 and no.7, respectively. Finally, the yearly optional grazing capacity, through the future period (2011-2030), was expressed by two values;10264 cattle and 41058 sheep.
\end{abstract}

Keywords: Northern West Coast, Egypt - El-Dabaa - watersheds - net outlets - flow accumulation forecasted crops - irrigation water requirements - land potential grazing capacity

\section{INTRODUCTION}

Climate is a vital natural resource to our well-being, health and prosperity. The information gathered, managed and analyzed helps decision-makers and users to plan and adapt their activities and projects for the expected conditions. In

Vol. 20(1), 2015 
this way, decisions may be taken in planning which reduce risks and optimize socio-economic benefits (Fildes and Kourentzes, 2015). They designed the scientific approach of forecasting the climate changes. International Research Institute for Climate and Society (2015) has output numerous models to forecast climate parameters, such as seasonal precipitation, seasonal temperature and temperature anomaly.

Rain Water Harvesting.org (2015) defined water harvest as capturing rain where it falls or capturing the run off in your own village or town. In addition, taking measures to keep that water clean by disallow polluting activities to take place in the catchment. It can serve to provide drinking and irrigation water, increase groundwater recharge, and to reduce storm water and urban floods.

Hamid et al. (2009) designed RS and GIS for decision support system to determine preference sites for water harvest at Eastern Nile locality - Sudan. This model had the objective to conserve water and avoid the floods. This idea of integrated RS and GIS was applied by numerous researches. Weerasinghe et al. (2011) used the assessment of several water related environmental challenges such as soil erosion, degradation of land by water logging, ground and surface water contamination, and ecosystem. They provided evidence for successful catchment management including reservoir system management, irrigation scheduling and risk management.

Ministry of Water Resources and Irrigation (2013) proposed the strategy of improving water harvesting. They reported that a big chance for storing increasing amounts of the rain falling by developing and improving traditional methods and introducing modern storing methods. Improve water-harvesting systems by Introducing geographic system for surveying the areas good for applying different water harvesting methods according to the nature of every area. Improving the storing rain water in sand lands like the Northeastern Coast and west of the Northwestern Coast (Brani-Al-Sallum) by selecting soil treatment materials to increase surface flow rate. They also informed that the analysis of meteorological data and the land's topographic study and the soil composition to set the appropriate models for rain water harvesting.

The main objective of this research is to present technological breakthroughs to reduce risks of food production relating to climate changes. So, a decision making supporting agro-system was built basing on the following parameters:

a- determination the location and capacity of water harvest reservoirs,

b- forecasting of crop evapotranspiration $\left(E T_{c}\right)$,

c- determination of plantation area by rain water harvest and

d- determination of land potential grazing capacity. 


\section{MATERIALS AND METHODS}

The North Western Coastal Region (NWCR) of Egypt is one of the most promising areas for agricultural development. It extends from Alexandria in the east to Sallum in the west with about $500 \mathrm{~km}$ width and $40 \mathrm{~km}$ depth. It is located

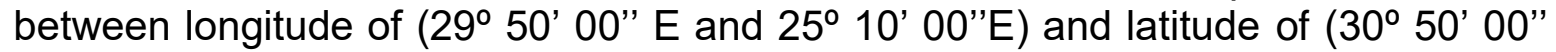
$\mathrm{N}$ and $31^{\circ} 10^{\prime} 00^{\prime \prime} \mathrm{N}$ ). The study area (El-Dabaa) covers an area of approximately 60490 hectares. It extends from $606259 \mathrm{E}$ to $651072 \mathrm{E}$ and from $3437982 \mathrm{~N}$ to $3416473 \mathrm{~N}$ (Fig., 1). The area is bounded to the north by the Alex-Matrouh road and on the south by Elgesh road.

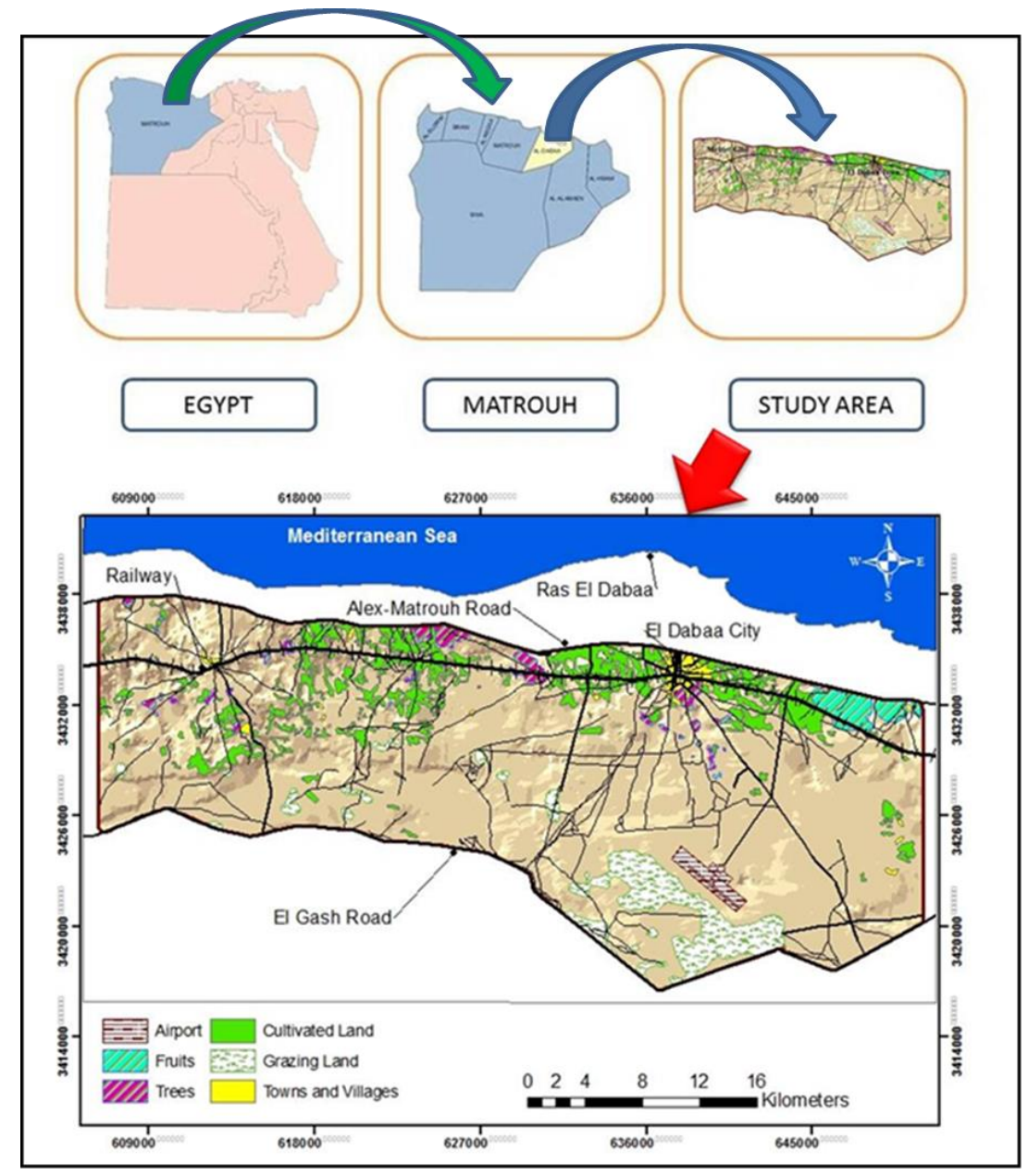

Fig. (1). Studied area (El-Dabaa) (606259 E to $651072 \mathrm{E}$ and $3437982 \mathrm{~N}$ to $3416473 \mathrm{~N})$ 
The current study was elaborated through four interrelated and independent phases as follows:

(1) Digitizing of the topographic maps: Four 1:50,000 scaled-topographic maps covering the studied area were digitized and clipping to create the mosaic of the studied region. The coordinate was converted from the geographic coordinates (Lat.-Long.) system to Universal Transverse Mercator (UTM) coordinates system ArcMap 10.0 (2010). Then the maps were registered by ENVI 4.5 (2008) and IAO (2010).

(2) GIS- geomorphological mapping: Digital Elevation Model (DEM) was derived from contour lines and spot heights were utilized by contour gridder extension under Arc View to create DEM with $15 \times 15 \mathrm{~m}$ spatial resolution. This DEM was conduct to a preliminary understanding of the geomorphology, and derivation of the drainage network. Slope gradient and slope aspects were derived from (DEM) to be classified as illustrated in Table (1), and Figure (2).

Table (1): Classes of gradient slope.

\begin{tabular}{cccccc}
\hline No. & Slope Class & Slope $\%$ & No. & Slope Class & Slope\% \\
\hline 1 & Flat & $0.0-0.5$ & 5 & Moderately sloping & $10-15$ \\
2 & Nearly level & $0.5-1$ & 6 & Strongly sloping & $15-30$ \\
3 & Gently slope & $1-5$ & 7 & Steep & $30-60$ \\
4 & Sloping & $5-10$ & 8 & Very steep & $>60$ \\
\hline
\end{tabular}

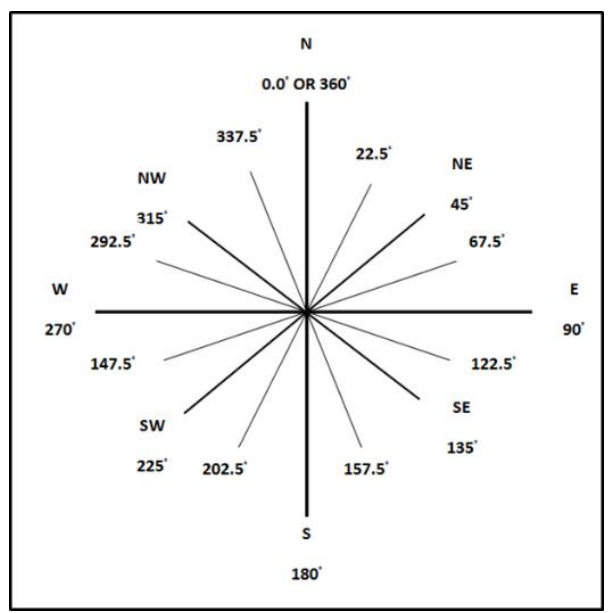

Fig. (2): Slope aspects classes and their Azimuth ranges.

(3) GIS - mapping of the surface hydrology: The surface hydrological outputs were obtained by running of (ArcGIS 10.0, 2010); watersheds (drainage basins and streams, and flow accumulation).

(4) Design supporting system of agricultural decision making: The system was built by integration of the following parameters (a) GIS-forecasted agroclimatic data of future period (2011-2030), (b) determination of location and capacity of 
basins reservoirs harvested water, (c) calculation of harvested water product, (d) calculation the optional planting areas of the dominated crops and (e) determination of potential grazing capacity.

(a) Forecasting Agroclimatic Data of future period (2011-2030): Agroclimatic data of future period (2011-2030) were forecasted (AbdEl-Hady et al, 2014) by applying time series statistical analysis (Fathony et al, 2009; ABS, 2011; Coghlan, $2015 \mathrm{a}$ and b) on agroclimatic data of the baseline period (1973-2010) Mersa Matruh, Egypt weather station. The potential evapotranspiration $\left(E T_{0}\right)$ were determined by using CropWat 8.0 application (FAO, 2009). Crop water requirements for the dominate growing crops was calculated using crop factor $\left(\mathrm{K}_{\mathrm{c}}\right)$ for each crop (Allen et al., 1998; Al-Najar, 2011).

(b) Determination of location and capacity of basins reservoirs harvested Water: Determination the location and capacity of basins reservoirs conducted to calculate harvested water reservoirs capacity at outlet grid cells as:

where:

$$
H W R C=P_{\max } \times R \times N \times S
$$

HWRC $=$ Harvested water reservoirs capacity $\left(\mathrm{m}^{3} /\right.$ year)

$\mathrm{P}_{\max }=$ maximum annual precipitation ( $\mathrm{m} / \mathrm{year}$ ) of the future agroclimatic data (2011-2030),

$R=$ factor of runoff adjusted,

$\mathrm{S}=$ surface area of outlet grid cell $\left(\mathrm{m}^{2}\right)$ and

$\mathrm{N}=$ number of accumulative cells of outlet.

Where $\mathrm{N}=$ (number of accumulative cells at the well) - (sum number of accumulative cells at the wells before it on the same stream line)

\section{(c) Calculation of harvested water product:}

$$
H W P=P_{\text {mean }} \times R \times N \times S
$$

where:

$$
\begin{aligned}
H W P= & \text { product of harvested water }\left(\mathrm{m}^{3} / \text { year }\right) \\
\mathrm{P}_{\text {mean }}= & \text { mean annual precipitation }(\mathrm{m} / \text { year) of the future agroclimatic data } \\
& (2011-2030) ; \mathrm{R}, \mathrm{N} \text { and } \mathrm{S} \text { are as noted above. }
\end{aligned}
$$

(d) Calculation the optional planting areas of the dominated crops: The compiling of forecasted net water requirements and harvested water reservoirs were used to calculate the total optional planting areas of the dominated crops; alfalfa, sorghum, wheat and barley.

(e) Determination of potential grazing Capacity: A common rule for estimating a properties potential carrying capacity or potential stocking rate. Potential stocking rate $($ head/ha $)=[($ Annual rainfall $\mathrm{mm}-250) \times 1.3] / 25$ (Attwood, 2007). It was difficult to apply this equation, hence the annual precipitation of the studied area generally less than $250 \mathrm{~mm} / \mathrm{year}$. Thus, grazing capacity was expressed by the number of cattle and sheep. 


\section{RESULTS}

(1) GIS- geomorphological characterization of the studied region:

The GIS-geomorphological characterization of the studied region was elaborated through the steps of:

a- Digitizing and Clipping; Four 1:50000 scaled-topographic maps of covering the study area were digitized using on the screen. Then, the area studied was clipped according its coordinates $606259 \mathrm{E}$ to $651072 \mathrm{E}$ and $3437982 \mathrm{~N}$ to $3416473 \mathrm{~N}$ (Fig., 2). The figure showed that the studied area that extends from Alexandria-Matrouh desert road at the north to Elgesh road has the following themes; cultivated land, fruits, trees and grazing land.

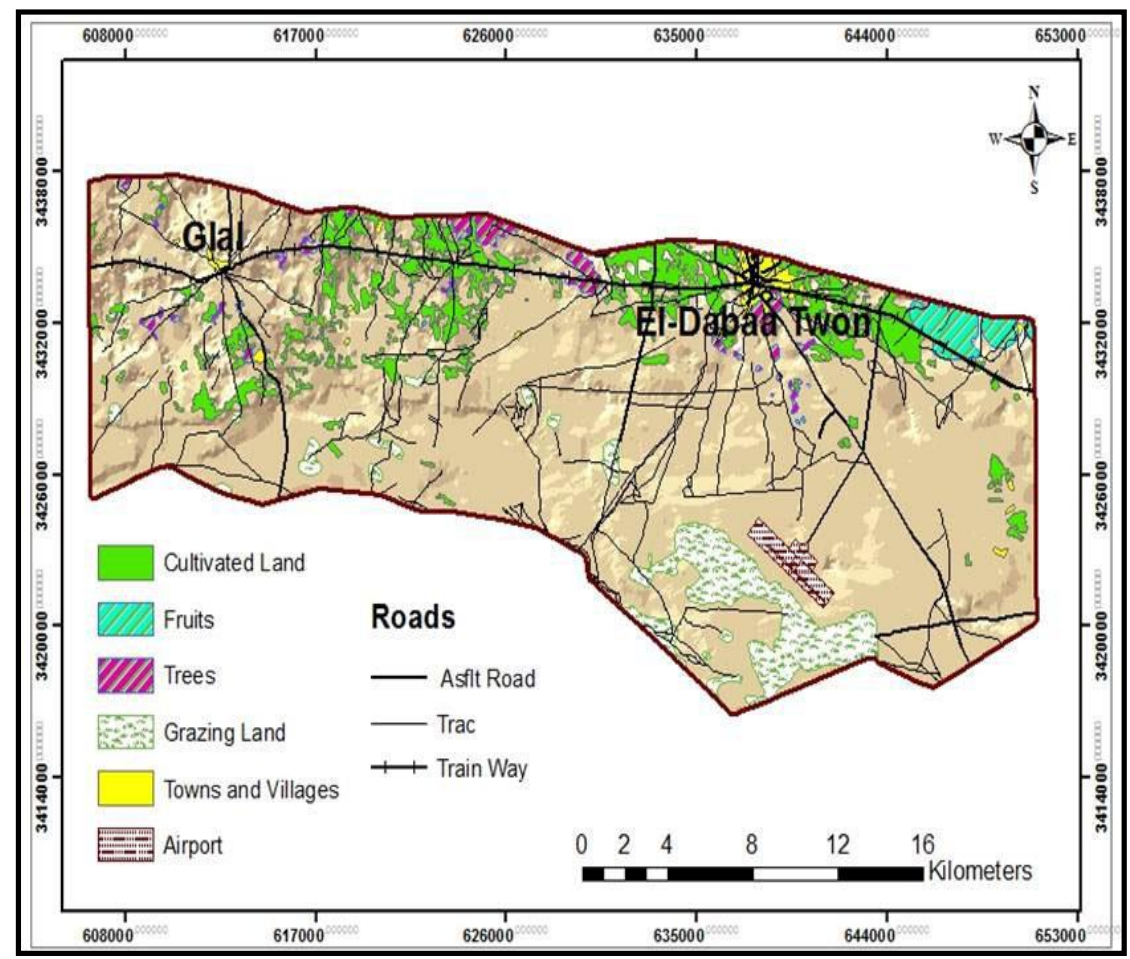

Fig. (2). Clipping of El-Dabaa area, Western North Coast, region, Egypt Coordinates: $606259 \mathrm{E}$ to $651072 \mathrm{E}$ and $3437982 \mathrm{~N}$ to $3416473 \mathrm{~N}$.

b- Digital Elevation Model (DEM): The digital elevation model (DEM) was displayed in Fig. (3). The figure showed that the elevation ranges from $10 \mathrm{~m}$ to 80 $m$ Above Sea Level (A.S.L). The dominant elevation class that has a percent of $22.1 \%$ of the studied area ranges from 30 to $40 \mathrm{~m} \mathrm{A.S.L.} \mathrm{About} 2.3 \%$ the region has an elevation ranges from $10 \mathrm{~m}$ to $20 \mathrm{~m}$ A.S.L. (Table 2) to present the elevation class of the smallest area. 
c- Slope gradients: Slope gradients were derived from the digital elevation model (DEM) as shown in Figure (3) and Table (2). The table illustrated that the studied area were practically divided into three slope gradient classes (FAO, 1990) that ranges from flat slope class $(0.0-0.5 \%)$ to gently slope class $(1-5 \%)$ with an area of $83.3 \%$ and $6.1 \%$, respectively. This indicated clearly that the majority of the studied area suited in the sloping class of flat that representing $83.3 \%$ of the area. The figure guided to determine the location of the interceptor drains. These drains are located across the direction of water flow at or near the interface where sloping land meets the flats (Fig., 3 ) as effective means of water harvest.

Table (2): DEM classes and area percentage of the studied area.

\begin{tabular}{cccccc}
\hline No. & $\begin{array}{c}\text { Elevation } \\
(\mathbf{m})\end{array}$ & $\%$ & No. & $\begin{array}{c}\text { Elevation } \\
(\mathbf{m})\end{array}$ & $\%$ \\
\hline 1 & $10-20$ & 2.3 & 5 & $50-60$ & 19.2 \\
2 & $20-30$ & 10.6 & 6 & $60-70$ & 15.4 \\
3 & $30-40$ & 22.1 & 7 & $70-80$ & 11.7 \\
4 & $40-50$ & 18.7 & & & \\
\hline
\end{tabular}

d- Slope aspect: Aspect was interpolated from DEM to illustrate the main slope directions (Fig. 3). The attributed aspect direction data (Table 3) indicated that the dominant aspect classes are of northeast, north and east. They represented an area of $64.5 \%$ of the studied region.

Table (3): Slope gradient classes.

\begin{tabular}{cccccccc}
\hline No. & $\begin{array}{c}\text { Slope } \\
\text { Gradient (\%) }\end{array}$ & $\begin{array}{c}\text { Slope Gradient } \\
\text { Classes }\end{array}$ & $\begin{array}{c}\text { Area } \\
(\%)\end{array}$ & No. Gradient \% & $\begin{array}{c}\text { lope Gradient } \\
\text { Classes }\end{array}$ & $\begin{array}{c}\text { Area } \\
(\%)\end{array}$ \\
\hline 1 & $0.0-0.5$ & Flat & 83.3 & 4 & $5-10$ & $\begin{array}{c}\text { Sloping } \\
\text { Moderately }\end{array}$ & 0.1 \\
2 & $0.5-1.0$ & Nearly level & 10.5 & 5 & $10-15$ & $\begin{array}{c}\text { sloping } \\
\text { Strongly sloping }\end{array}$ & 0.0005 \\
3 & $1-5$ & Gently slope & 6.1 & 6 & $15-30$ & Strong \\
\hline
\end{tabular}




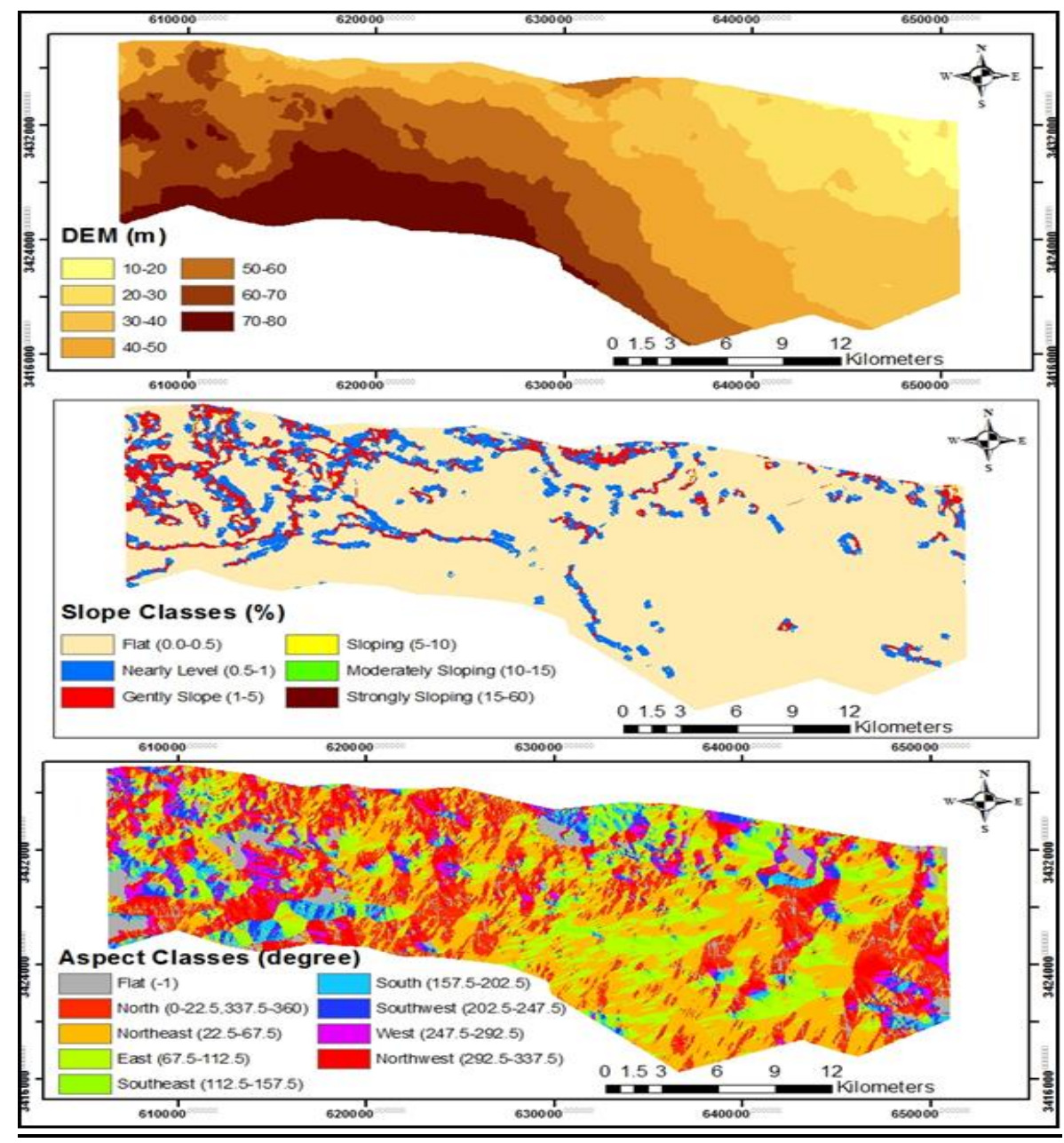

Fig. (3). Geomorphological features, digital elevation model (DEM), gradient and aspects maps

\section{GIS- study of the surface hydrology:}

a- Watersheds were derived from the digital elevation model (DEM), Fig (4). The figure illustrated that the watersheds of El-Dabaa studied area are distributed through fourteen basins that have an area ranged between $8.6 \mathrm{~km}^{2}$ (basin, 11) to $136.8 \mathrm{~km}^{2}$ (basin, 4), Table (4).

Table (4): Attributed data of aspect directions.

\begin{tabular}{cccccc}
\hline No. & Direction & $\%$ & No. & Direction & $\%$ \\
\hline 1 & Flat & 6.5 & 6 & South & 4.4 \\
2 & North & 18.4 & 7 & Southwest & 4.2 \\
3 & Northeast & 32 & 8 & West & 4.9 \\
4 & East & 14.1 & 9 & Northwest & 9.6 \\
5 & Southeast & 5.9 & & & \\
\hline
\end{tabular}




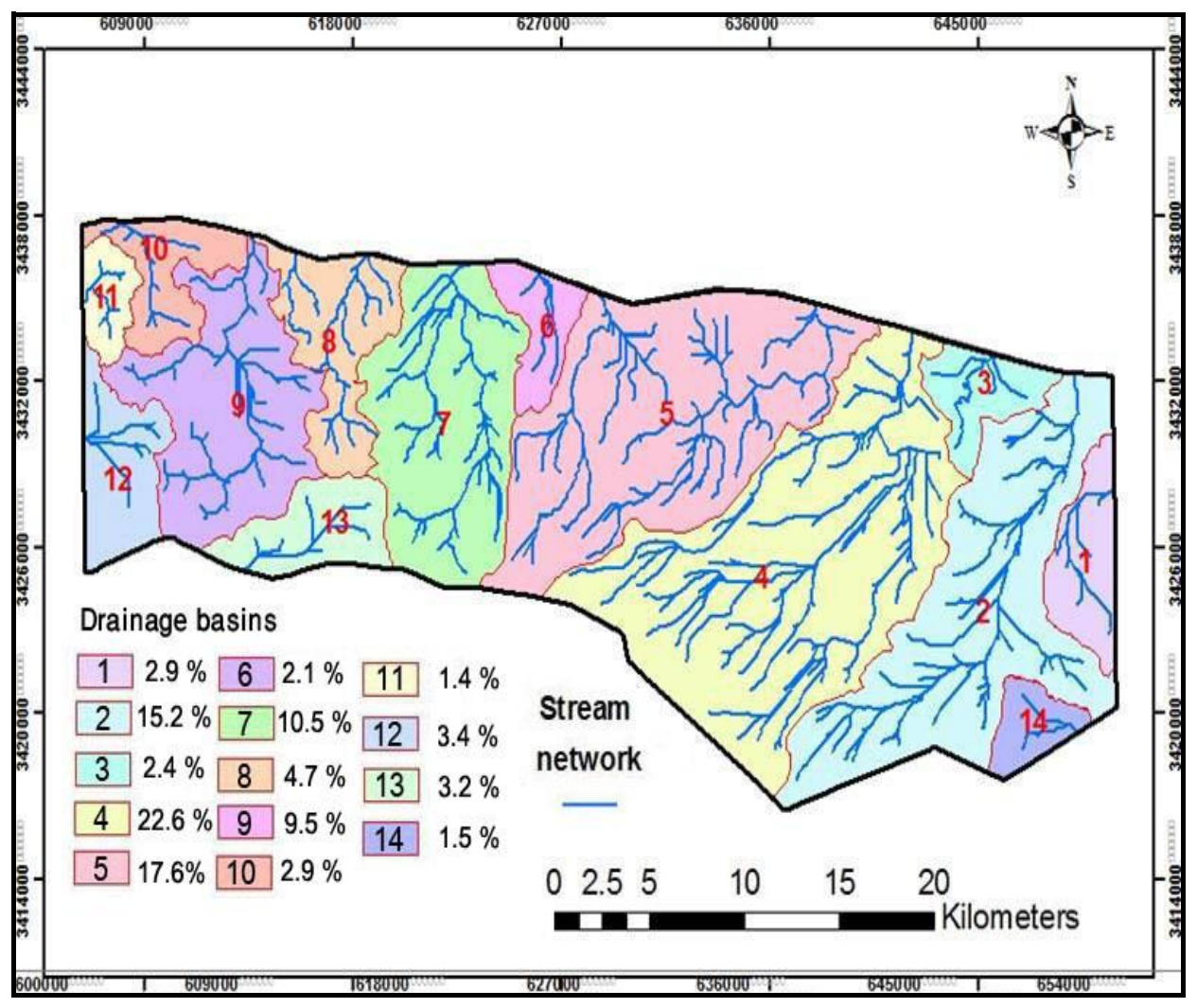

Fig. (4). Watersheds of the studied area; drainage basins and streams.

Table (5): Area of watershed basins.

\begin{tabular}{cccccc}
\hline Basin No. & $\mathbf{K m}^{2}$ & Area \% & Basin No. & $\mathbf{K m}^{2}$ & Area \% \\
\hline 1 & 17.4 & 2.9 & 8 & 28.7 & 4.7 \\
2 & 92.0 & 15.2 & 9 & 57.7 & 9.5 \\
3 & 14.6 & 2.4 & 10 & 17.6 & 2.9 \\
4 & 136.8 & 22.6 & 11 & 8.6 & 1.4 \\
5 & 106.2 & 17.6 & 12 & 20.8 & 3.4 \\
6 & 12.5 & 2.1 & 13 & 19.3 & 3.2 \\
7 & 63.4 & 10.5 & 14 & 9.3 & 1.5 \\
\hline
\end{tabular}

b- Flow Accumulation: The figure of flow accumulation (Fig. 5) indicated that the studied region has large seven flow accumulation that have the direction from south to north. This map provided accumulated flow data that were latter used to determine the location and water capacity of the reservoir basins. 


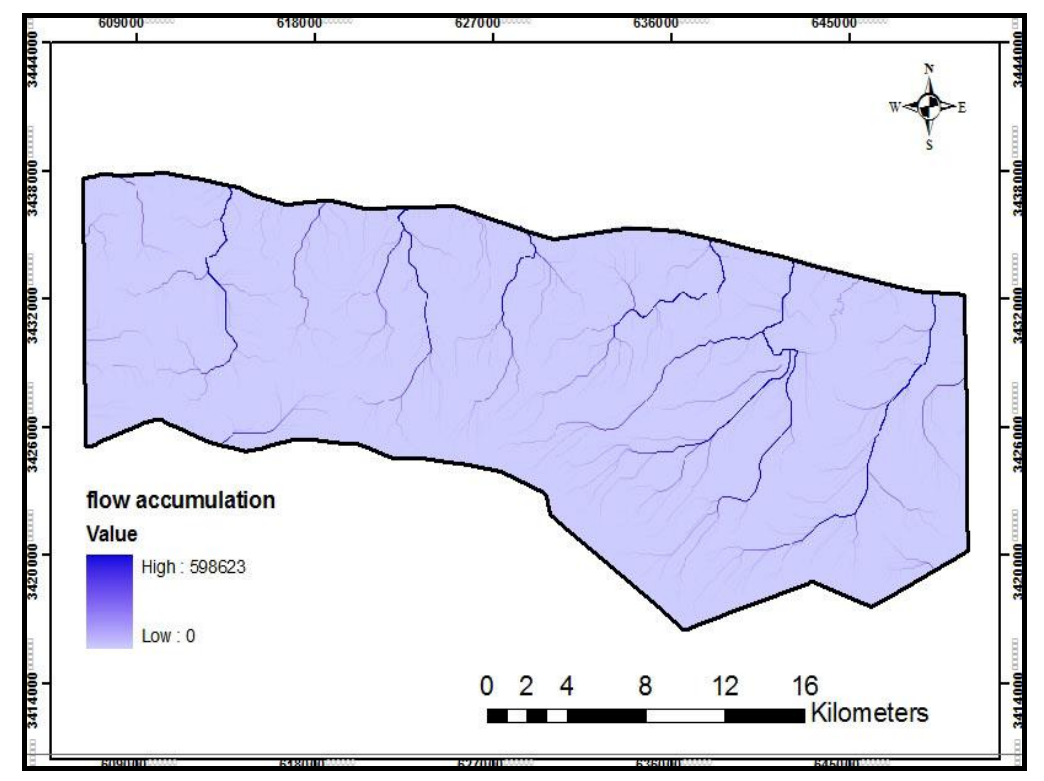

\section{Fig (5). Flow accumulation of El-Dabaa studied area}

\section{(3) Design supporting system of agricultural decision making:}

\section{a- GIS-forecasted agroclimatic data of future period (2011-2030):}

The agroclimatic data; average temperature, monthly precipitation rate and potential evapotranspiration ( $\mathrm{ET}_{0}$ ) were forecasted (Abd El-Hady et al, 2014) to calculate the net irrigation of water of the dominate crops. The area will be climatically characterized, in the future period of $(2011-2030)$ by $20.66{ }^{\circ} \mathrm{C}, 13.46$ $\mathrm{mm}$ and $87.7 \mathrm{~mm}$ for temperature, monthly precipitation and potential evapotranspiration $\left(\mathrm{ET}_{0}\right)$, respectively.

\section{b- Location and capacity of harvested rainwater reservoir:}

Location and capacity of harvested rainwater reservoir determined according to output data of stream network (Fig. 6). The figure showed that the area has twenty eight locations that were suitable to build harvested water reservoirs that were defined by their number and coordinates (Table 6). The figure also indicated that drainage basins had a different area and number of harvested water reservoirs. Drainage basin no. 4 had the largest area $\left(136.8 \mathrm{Km}^{2}\right)$ to contain five suitable water reservoirs locations (no. 6, 7, 8, 9 and 10). Four water reservoirs locations (no.11, 12,13 and 14) were located in the drainage basin (no. 5). Three water reservoirs location were localized in the each basins of no. 7 and 9 . These reservoirs have the numbers $(16,17$ and 18$)$ and $(21,22$ and 23$)$, respectively. Two reservoirs can be built in the basin (no.8). Finally each of the remaining basins contains only a location of harvested water reservoir. 
Table (6): GIS- recommended harvested water reservoirs locations

\begin{tabular}{|c|c|c|c|c|c|c|c|}
\hline \multirow{3}{*}{$\begin{array}{l}\text { Basin } \\
\text { No. }\end{array}$} & \multicolumn{3}{|c|}{$\begin{array}{c}\text { Recommended Harvested } \\
\text { Water Reservoirs }\end{array}$} & \multirow{3}{*}{$\begin{array}{c}\text { Basin } \\
\text { No. }\end{array}$} & \multicolumn{3}{|c|}{$\begin{array}{c}\text { Recommended Harvestec } \\
\text { Water Reservoirs }\end{array}$} \\
\hline & \multirow{2}{*}{ No. } & \multicolumn{2}{|c|}{ Coordinates } & & \multirow{2}{*}{ No. } & \multicolumn{2}{|c|}{ Coordinates } \\
\hline & & E & $\mathbf{N}$ & & & $\mathbf{E}$ & $\mathbf{N}$ \\
\hline \multirow[t]{2}{*}{1} & 1 & 650549 & 3427969 & 6 & 15 & 626142 & 3435731 \\
\hline & 2 & 649243 & 3432279 & & 16 & 622966 & 3436262 \\
\hline \multirow[t]{2}{*}{2} & 3 & 647726 & 3427727 & 7 & 17 & 623578 & 3430889 \\
\hline & 4 & 645357 & 3421879 & & 18 & 621071 & 3432334 \\
\hline \multirow[t]{3}{*}{3} & 5 & 645673 & 3432995 & & 19 & 618611 & 3436606 \\
\hline & 6 & 642161 & 3433827 & 8 & 20 & 617276 & 3432045 \\
\hline & 7 & 640677 & 3430403 & & 21 & 613453 & 3437341 \\
\hline \multirow[t]{4}{*}{4} & 8 & 639932 & 3422567 & 9 & 22 & 612549 & 3433276 \\
\hline & 9 & 638067 & 3425475 & & 23 & 613452 & 3430442 \\
\hline & 10 & 632069 & 3426033 & 10 & 24 & 607828 & 3437808 \\
\hline & 11 & 638007 & 3434731 & 11 & 25 & 606493 & 3435005 \\
\hline \multirow{3}{*}{5} & 12 & 632965 & 3430656 & 12 & 26 & 606395 & 3429977 \\
\hline & 13 & 628406 & 3435273 & 13 & 27 & 613258 & 3425165 \\
\hline & 14 & 627432 & 3431043 & 14 & 28 & 648912 & 3419589 \\
\hline
\end{tabular}

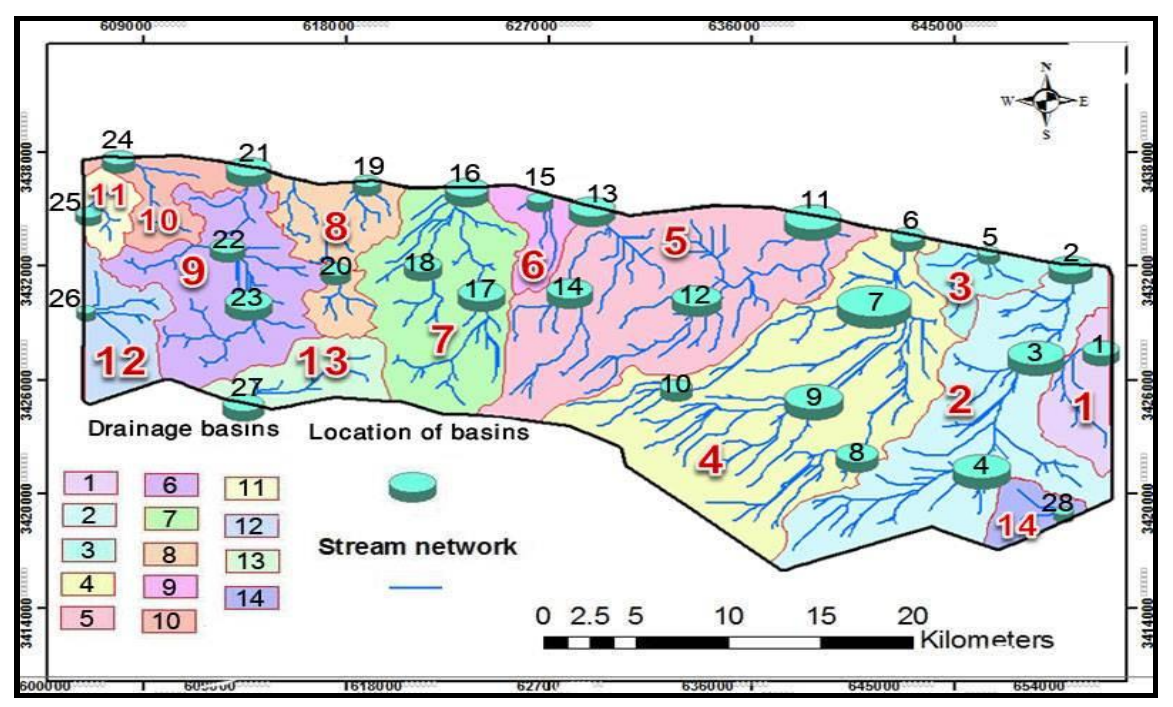

Fig. (6): Basins (red number) and location of water reservoirs (black number).

The capacity of the twenty eight water reservoirs was determined by based on (a) number of accumulative cells, (b) slope gradient, (c) maximum precipitation rate of the future climate period and (d) run coefficient (Table 6 and Fig. 7). The table referred to the construction of water reservoir at the location 7 (large one) may harvest $278828 \mathrm{~m}^{3} /$ year. The descriptive statics indicated that the construction of these twenty eight water reservoirs may supply the population by 2604325 $\mathrm{m}^{3} /$ year (more than two millions $\mathrm{m}^{3}$ of water). 


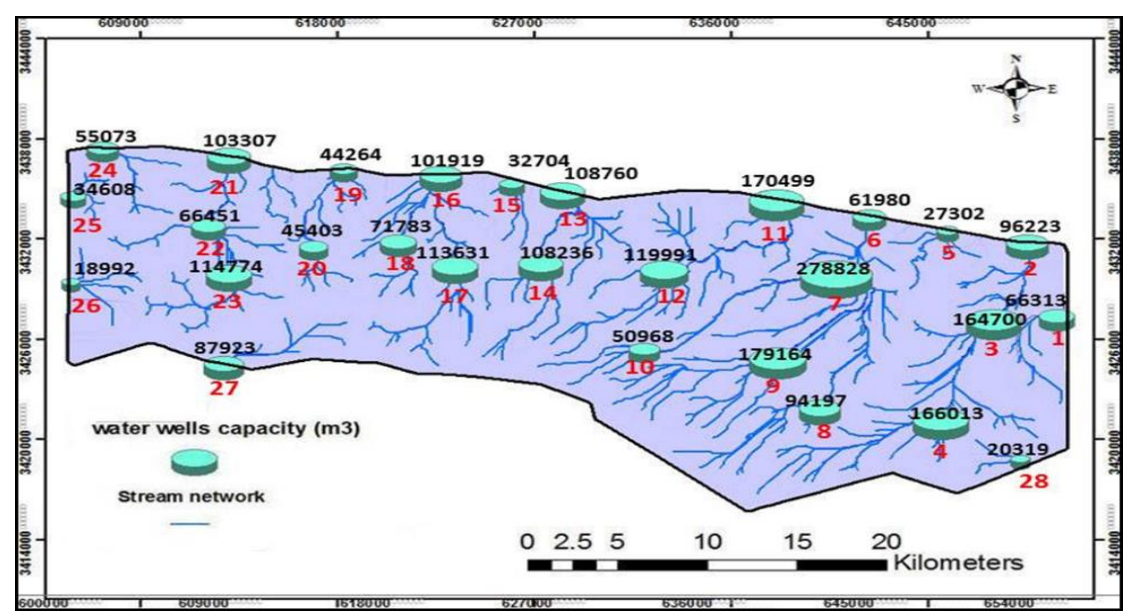

Fig. (7). Water reservoirs capacity $\left(\mathrm{m}^{3} / \mathrm{year}\right)$ for the future climate period (2011 -2030).

\section{c- Calculation of harvested water product:}

The integration of the averaged mean annual precipitation, output data of water streams and slope gradient map, led to calculate the harvested water product of each reservoir (Table 7$)$. The table illustrated that maximal $\left(227917 \mathrm{~m}^{3} /\right.$ year) and minimal (15524 $\mathrm{m}^{3} /$ year) will be collected in reservoir no.7 (basin no. 4) and reservoir no.26 (basin no. 14), respectively. The global annual harvest water product, for each year of the future period (2011-3030), may be $2604325 \mathrm{~m}^{3}$ (more than two millions $\mathrm{m}^{3}$ of water).

Table (7): Water reservoirs capacity $\left(\mathrm{m}^{3} /\right.$ year) and harvested water product of the future climate period (2011-2030)

\begin{tabular}{|c|c|c|c|c|c|c|c|}
\hline $\begin{array}{c}\text { Basin } \\
\text { No. }\end{array}$ & $\begin{array}{l}\text { water } \\
\text { reservoirs } \\
\text { No }\end{array}$ & $\begin{array}{c}\text { Water } \\
\text { Reservoirs } \\
\text { Capacity }\end{array}$ & $\begin{array}{l}\text { Harvested } \\
\text { Water } \\
\text { Product }\end{array}$ & \multirow[t]{2}{*}{$\begin{array}{c}\text { Basin } \\
\text { No. }\end{array}$} & \multirow[t]{2}{*}{$\begin{array}{c}\text { water } \\
\text { reservoirs } \\
\text { No. }\end{array}$} & $\begin{array}{l}\text { Water } \\
\text { Reservoirs } \\
\text { Capacity }\end{array}$ & $\begin{array}{l}\text { Harvested } \\
\text { Water } \\
\text { Product }\end{array}$ \\
\hline & & \multicolumn{2}{|c|}{$\left(\mathrm{m}^{3} /\right.$ year$)$} & & & \multicolumn{2}{|c|}{ (m $m^{3} /$ year) } \\
\hline \multirow[t]{2}{*}{1} & 1 & 66313 & 54205 & 6 & 15 & 32704 & 26733 \\
\hline & 2 & 96223 & 78654 & & 16 & 101919 & 83310 \\
\hline \multirow[t]{2}{*}{2} & 3 & 164700 & 134628 & 7 & 17 & 113631 & 92884 \\
\hline & 4 & 166013 & 135701 & & 18 & 71783 & 58677 \\
\hline \multirow[t]{3}{*}{3} & 5 & 27302 & 22317 & & 19 & 44264 & 36182 \\
\hline & 6 & 61980 & 50663 & 8 & 20 & 45403 & 37113 \\
\hline & 7 & 278828 & 227917 & & 21 & 103307 & 84444 \\
\hline \multirow[t]{4}{*}{4} & 8 & 94197 & 76998 & 9 & 22 & 66451 & 54318 \\
\hline & 9 & 179164 & 146451 & & 23 & 114774 & 93818 \\
\hline & 10 & 50968 & 41662 & 10 & 24 & 55073 & 45018 \\
\hline & 11 & 170499 & 139368 & 11 & 25 & 34608 & 28289 \\
\hline \multirow{3}{*}{5} & 12 & 119991 & 98082 & 12 & 26 & 18992 & 15524 \\
\hline & 13 & 108760 & 88902 & 13 & 27 & 87923 & 71870 \\
\hline & 14 & 108236 & 88473 & 14 & 28 & 20319 & 16609 \\
\hline
\end{tabular}

Vol. 20(1), 2015 
(d) Calculation of the optional planting areas of the dominate crops:

Results of forecasting crops water requirements showed clearly that alfalfa needs largest one (1275 mm/year), meanwhile the barley crop was had smallest water requirements $(247 \mathrm{~mm} / \mathrm{season})$. Wheat and sorghum requires less irrigation water; 250 and $330 \mathrm{~mm} /$ season, respectively (Table 8).

Table (8): Forecasted crop water requirements (CWR), $\mathrm{mm} / \mathrm{season}$.

\begin{tabular}{cccccc}
\hline Crop & Alfalfa & Sorghum & Wheat & Barley & Maize \\
\hline CWR & 1275 & 330 & 250 & 247 & 360 \\
\hline
\end{tabular}

The determination of the optional area of the crops was based on (a) crops water requirements and (b) capacity of water reservoir which calculated by mean precipitation rate of the future climate period (Table 9). The results generally indicated that larger area could be planted by wheat and barley than alfalfa and sorghum. It is recommended rejecting the option of alfalfa plantation because they needs large water requirements. The data concluded that the optional planting areas may be 1535.9, 2027.4, and 2052.1 (feddans/season) for sorghum, wheat and barley, respectively (Fig. 8).

Table (9): The optional planting areas of the dominant crops on the recommended rainwater reservoirs.

\begin{tabular}{|c|c|c|c|c|c|c|c|c|c|}
\hline \multirow{2}{*}{ 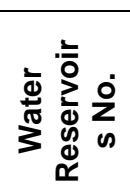 } & \multicolumn{4}{|c|}{ Crop Area (fed.) } & \multirow{2}{*}{ 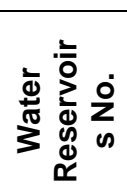 } & \multicolumn{4}{|c|}{ Crop Area (fed.) } \\
\hline & Alfalfa & Sorghum & Wheat & Barley & & Alfalfa & Sorghum & Wheat & Barley \\
\hline 1 & 10.12 & 39.11 & 51.62 & 52.25 & 15 & 4.99 & 19.29 & 25.46 & 25.77 \\
\hline 2 & 14.69 & 56.75 & 74.91 & 75.82 & 16 & 15.56 & 60.11 & 79.34 & 80.31 \\
\hline 3 & 25.14 & 97.13 & 128.22 & 129.77 & 17 & 17.35 & 67.02 & 88.46 & 89.54 \\
\hline 4 & 25.34 & 97.91 & 129.24 & 130.81 & 18 & 10.96 & 42.34 & 55.88 & 56.56 \\
\hline 5 & 4.17 & 16.1 & 21.25 & 21.51 & 19 & 6.76 & 26.11 & 34.46 & 34.88 \\
\hline 6 & 9.46 & 36.55 & 48.25 & 48.84 & 20 & 6.93 & 26.78 & 35.35 & 35.78 \\
\hline 7 & 42.56 & 164.44 & 217.06 & 219.7 & 21 & 15.77 & 60.93 & 80.42 & 81.4 \\
\hline 8 & 14.38 & 55.55 & 73.33 & 74.22 & 22 & 10.14 & 39.19 & 51.73 & 52.36 \\
\hline 9 & 27.35 & 105.66 & 139.48 & 141.17 & 23 & 17.52 & 67.69 & 89.35 & 90.44 \\
\hline 10 & 7.78 & 30.06 & 39.68 & 40.16 & 24 & 8.41 & 32.48 & 42.87 & 43.4 \\
\hline 11 & 26.03 & 100.55 & 132.73 & 134.34 & 25 & 5.28 & 20.41 & 26.94 & 27.27 \\
\hline 12 & 18.32 & 70.77 & 93.41 & 94.55 & 26 & 2.9 & 11.2 & 14.78 & 14.96 \\
\hline 13 & 16.6 & 64.14 & 84.67 & 85.7 & 27 & 13.42 & 51.85 & 68.45 & 69.28 \\
\hline 14 & 16.52 & 63.83 & 84.26 & 85.28 & 28 & 3.1 & 11.98 & 15.82 & 16.01 \\
\hline \multicolumn{6}{|c|}{ Total } & 397.6 & 1535.9 & 2027.4 & 2052.1 \\
\hline
\end{tabular}

Leaching fraction and efficiencies were not considered, Feddan $=4200 \mathrm{~m}^{2}$ 


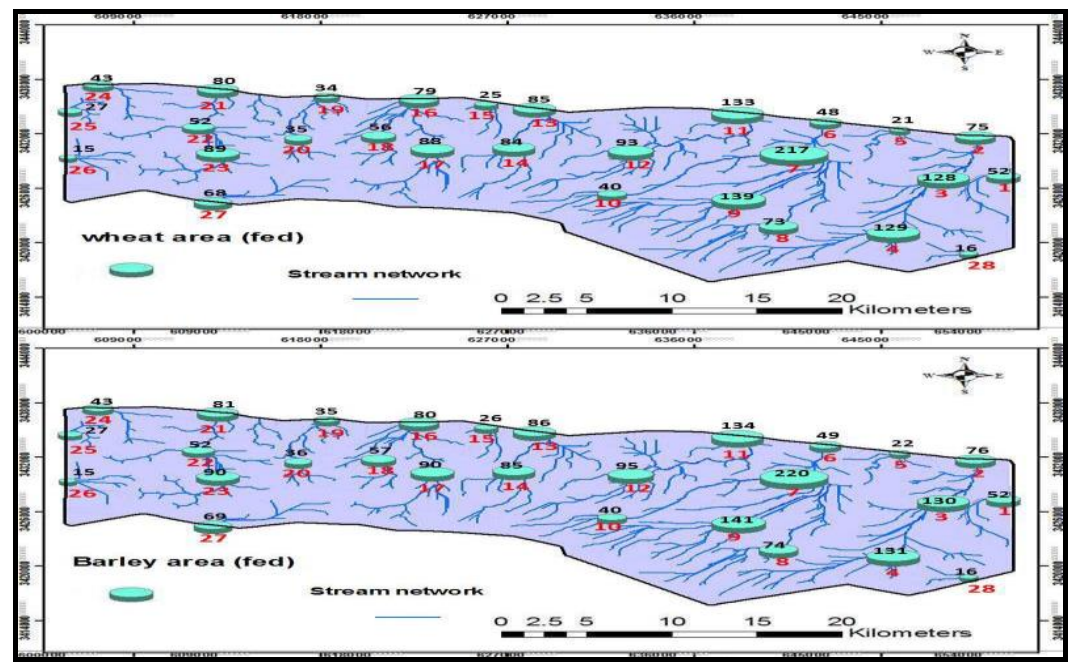

Fig. (8-a). Wheat and barley plantation area (2011-2030) using forecasted rainwater harvest.

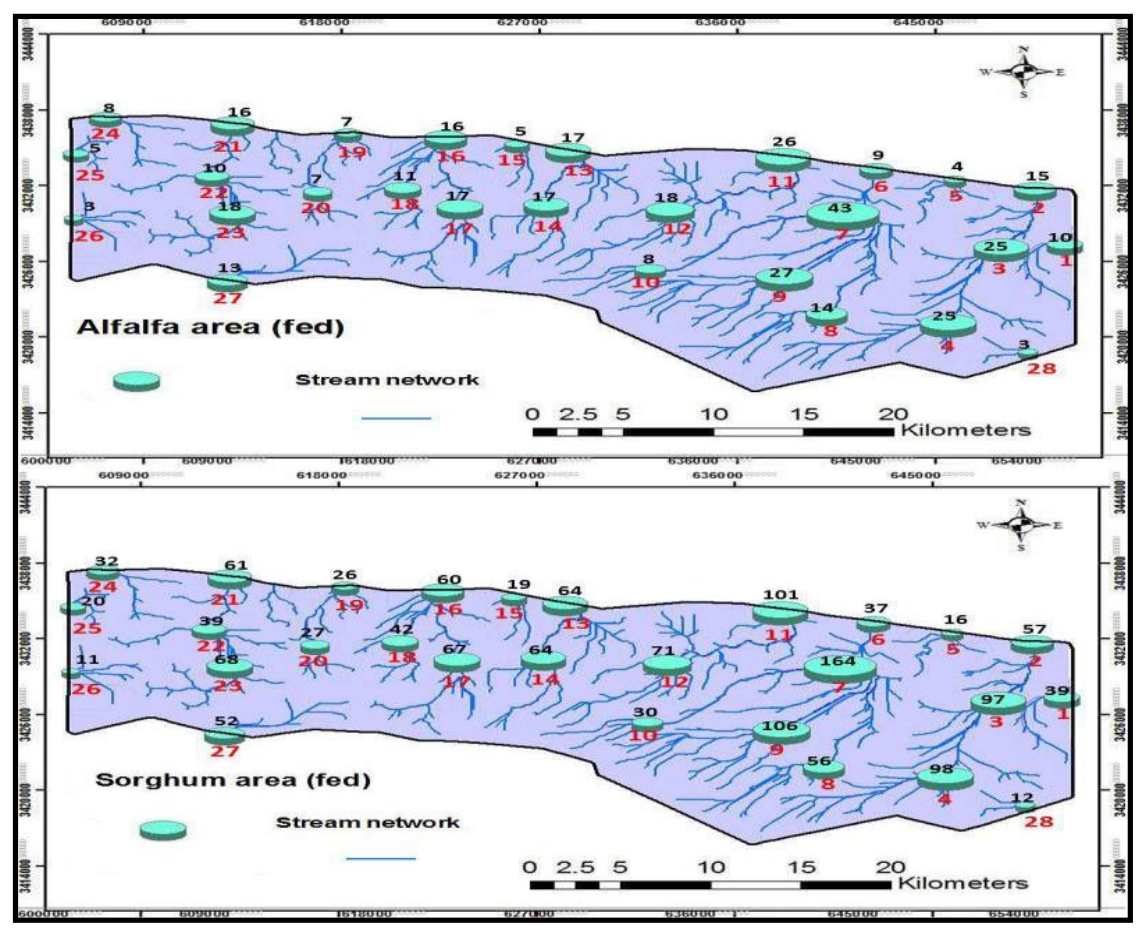

Fig (8-b). Alfalfa and sorghum plantation area (2011-2030) using forecasted rainwater harvest.

(e) determination optional grazing capacity: 
Hence barely needs least water requirements for grazing capacity, surrounding each water reservoir, was calculated and expressed by number of cattle and sheep (Table 10, and Fig. 9). This calculation proposes that barley grazing capacity is five and twenty heads/feddan for cattle and sheep, respectively. The data showed that barley grazing capacity may have the ranges of 75 - 1099 cattle and $299-4396$ sheep surrounding reservoir no. 7 and 26, respectively (Table 10). Finally, the yearly optional grazing capacity, through the future period (2011-2030), was expressed by two values; 10264 cattle and 41058 sheep.

Table (10): Potential grazing capacity under barley plantation.

\begin{tabular}{cccccc}
\hline Well No. & Cattle No. & Sheep No. & Well No. & Cattle No. & Sheep No. \\
\hline 1 & 261 & 1045 & 15 & 129 & 516 \\
2 & 379 & 1517 & 16 & 402 & 1607 \\
3 & 649 & 2596 & 17 & 448 & 1791 \\
4 & 654 & 2617 & 18 & 283 & 1132 \\
5 & 108 & 430 & 19 & 174 & 698 \\
6 & 244 & 977 & 20 & 179 & 716 \\
7 & 1099 & 4396 & 21 & 407 & 1629 \\
8 & 371 & 1485 & 22 & 262 & 1048 \\
9 & 706 & 2825 & 23 & 452 & 1809 \\
10 & 201 & 804 & 24 & 217 & 868 \\
11 & 672 & 2688 & 25 & 136 & 546 \\
12 & 473 & 1892 & 26 & 75 & 299 \\
13 & 429 & 1715 & 27 & 347 & 1386 \\
14 & 427 & 1706 & 28 & 80 & 320 \\
\hline \multicolumn{7}{c}{ total } & & 10264 & 41058 \\
\hline
\end{tabular}




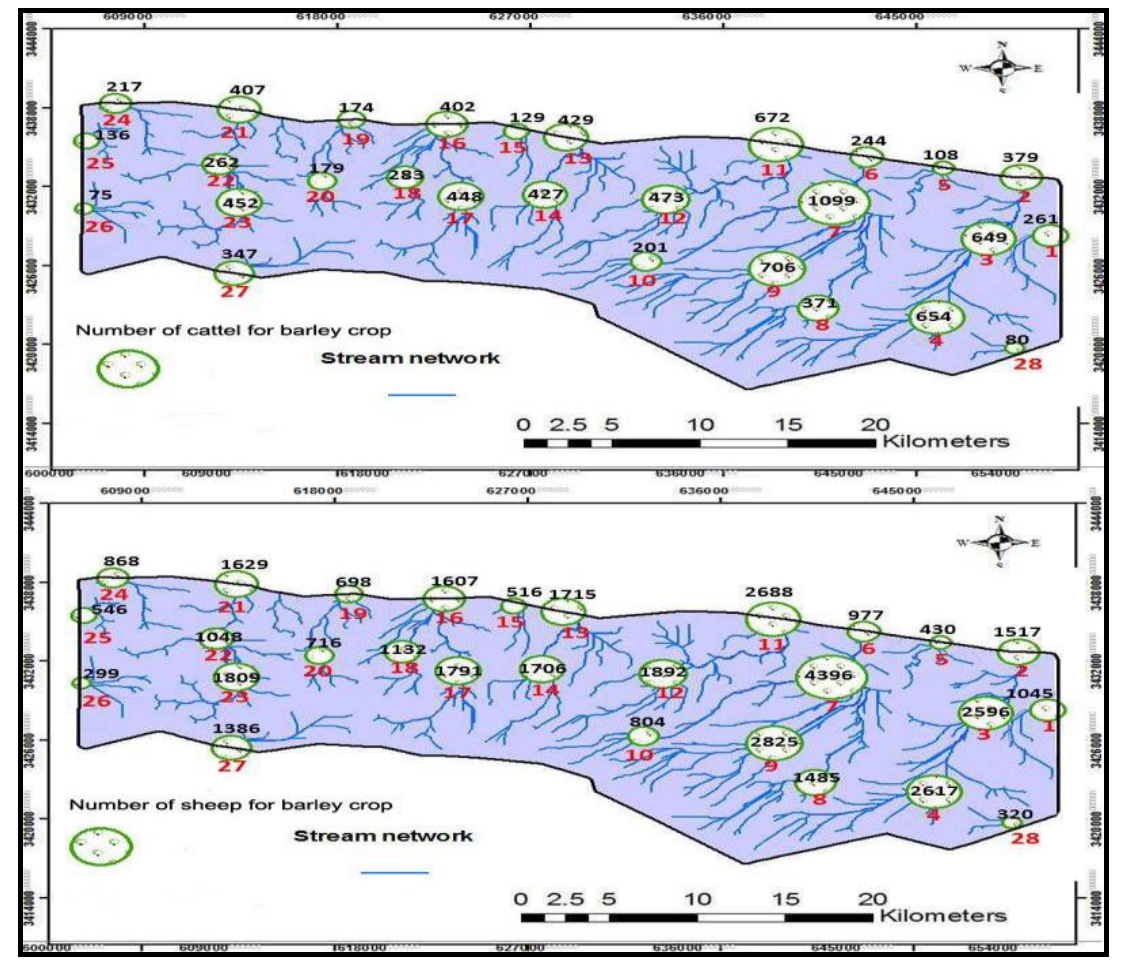

Fig. (9). Cattle and sheep grazing on barley irrigated by forecasted harvested water for each year of the future period (2011-2030).

\section{DISCUSSION}

The forecasted of precipitation rate showed that December month still the highest month in precipitation rate with maximum value $(78.70 \mathrm{~mm} / \mathrm{month})$ during the future climate period that has general mean was $(13.46 \mathrm{~mm} / \mathrm{month})$. According to output data of stream network, the area has twenty eight locations that were suitable to build harvested water reservoirs. Therefore, decision makers can start to construct water reservoir at the location 7 to harvest about $278828 \mathrm{~m}^{3} / \mathrm{year}$ and continue to complete construction of the twenty eight water reservoirs to harvest about $2604325 \mathrm{~m}^{3} /$ year. Concerning to the rain water harvest, the larger area can be planted by wheat and barley than alfalfa and sorghum. It is recommend to reject the option of alfalfa plantation because of it large water requirements. Based on the barley crop that can be planted by water harvested in each well. The number of cattle that can be grazed ranged from 75 head to 1099 head while the number of sheep ranged from 299 head to 4396 head.

\section{CONCLUSION}

The integration of GIS- surface hydrology and forecasted agroclimate data was conducted to locate the sites of the harvested rainwater. Agroclimate data can be accurately determined by elaboration time series analyses that require reliable

Vol. 20(1), 2015 
series decomposition. Large amount of rainwater can be harvested, as example more two millions $\mathrm{m}^{3}$ of water can be collected into fourteen reservoirs at El-Dabaa studied area. Finally, this research may present technological breakthroughs, to reduce risks of food production relating to climate changes, by building a decision making supporting agro-system.

\section{REFERENCES}

Abd El-Hady A.M., Aggag A.M., Abdelaty E.F., Bahnassy M.H. (2014). Forecasting of Water Crisis and Water Requirements of Wheat Cultivated at the Northern West Coast (Egypt). 17th Annual Energy, Utility and Environment Conference: EUEC 2014, 3-5 Feb, Phoenix Convention Center, Arizona, USA.

ABS (2011). Australian Bureau of Statistics. Time Series Analysis: The Basics. http://www.abs.gov.au/websitedbs/D3310114.nst/home/home?opendocument \#from-banner=GT.

Al-Najar, H. (2011). The Integration of FAO-CropWat Model and GIS Techniques for Estimating Irrigation Water Requirement and Its Application in the Gaza Strip. Natural Resources, 2: 146-154.

Allen R.G., Pereira L.S., Raes D., Smith M. (1998) Crop Evapotranspiration, Guidelines for Computing Crop Water Requirements. Irrigation and Drainage Paper No. 56, FAO, Rome, p. 300.

ArcMap 10.0 (2010). ESRI, Environmental Systems Research Institute. U.S. copyright $2010 \mathrm{ESRI}$ Inc.

Attwood, Mc. B. (2007). Grazing Requirements of Fibre and Meat Goats, http://new.dpi.vic.gov.au/agriculture/animals-andlivestock/goats/grazingrequirements-fibre.

Coghlan A. (2015 a). Time series analysis : R-3.1.2win.exe. http://www.r-project.org/

Coghlan A. (2015 b). A Little Book of R For Time Series, Release 2.0

https://media.readthedocs.org/pdf/a-little-book-of-r-for-time-series/latest/a- little-bookof-r-for-time-series.pdf

CropWat 8.0 (2009). Crop Water Requirements. Water Resources Development and Management Service of FAO.

http://www.fao.org/nr/water/infores_databases_cropwat.html

ENVI. (2008). Environment for Visualizing Image, version 4.5. ITT Visual Information Solutions. www.ittvis.com.

FAO (1990). Guidelines for Soil Profile Description. $3^{\text {rd }}$ ed., FAO, Rome.

Fathony R.Z.A.,Wibowo S.H. and Amelia L. (2009). Zaitun time series. Free time series analysis and forecasting software. Copyright@ zaitunsoftware.com 2009.

Fildes R., Kourentzes N. (2015). Climate Forecasting: what is required for scientific forecasting of climate changes. World Meteorological Organization. http://www.wmo.int/pages/themes/climate/long_range_forecasting.php

Hamid A., Al-Nair A., Yousif B. S., Galal M. H., Al-Tayeb M.Y. ( 2009 ). RS \& GIS for decision support system: Model for determining preference sites for water harvest (Eastern Nile locality - Sudan). 
IAO. (2010). Geographic Information Systems Knowledge base and applications. 30th Course on Geomatics and Natural Resources Evaluation. http://www.iao.florence.it/training/remotesensing,IAO, Florence.

International Research Institute for Climate and Society (2015). Forecast Products. http://iri.columbia.edu/our-expertise/climate/forecasts/seasonalclimate-forecasts/

Ministry of Water Resources and Irrigation. (2013). Development of the Northwestern Coast and its Desert Hinterland. http://www.emwis-eg.org/data\%20management\%2020irrigation\%20projectes\%20-north\%20coeast.htm.

Rain Water Harvesting.org (2015). What is the Water Harvesting? http://www.rainwaterharvesting.org/index.html

Weerasinghe H., Schneider U.A. and Low A. ( 2011). Waterharvest and storagelocation assessment model using GIS and remote sensing. j. Hydrology and Earth System Sciences Discussions, 8: 3356-3581.

http://www.hydrol-earth-syst-sci-discuss.net/8/3353/2011/hessd-8-3353-2011print.pdf. 


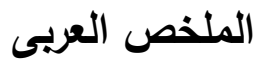

\section{التنبؤ بالهيلرولوجيا السطحية باستخدام نظم المعلومات الجغرافية للحد من مخاطر إنتاج الغذاء (الساحل الثمالى الغزبي - مصر)}

عبدرب النبى محمد عبد الهادى1 و أحمد محمد عجاج" و عماد فوزى عبد العاطى 12

(1) أستاذ وأستاذ مساعد ومدرس الموارد الطبيعية والهندسة الزراعية كلية الزراعة - جامعة دمنهور

(2) أستاذ الأراضى والمياه كلية الزراع بالثاطبى - جامعة الإسكندربة ومداد

منطقة الساحل الثمالى الغربى بمصر واحدة من أكثر المناطق الواعدة للتتمية الزراعية. فهي تمتد من الإسكندرية شرقاً

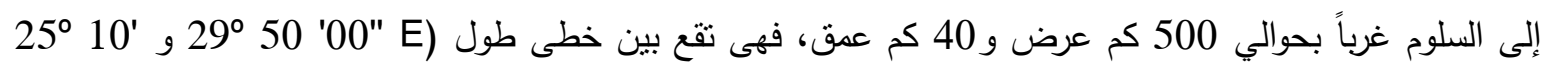

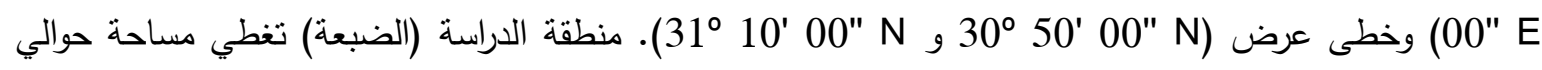

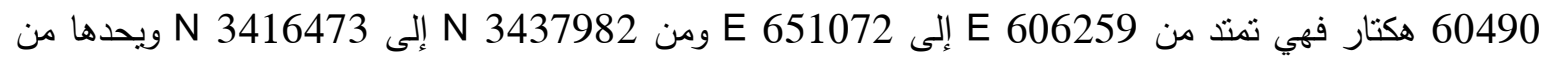
الثمال طريق الإسكندرية مطروح ومن الجنوب طريق الجيش. استخدمت أربعة خرائط طبوغرافية بمقياس رسم 1:50000 تغطى منطقة الدراسة بعد تحويلها الى صورة رقمية ونم تحديد مناطق تجميع المياه بمنطقة الضبعة والمشتقة من نموذج الارتفاع الرقمي (DEM) ووجد انها نتكون من أربعة عشر حوضاً بمساحات نتراوح بين 8.6 إلى 136.8 كم². كما أظهرت شبكة ممرات المياه ثمانية وعشرون مخرجاً للشبكة والتي تعنبر ثمانية وعشرون مكاناً

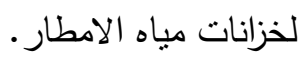

تتير خرائط تجميع التدفق ان منطقة الدراسة احتوت على سبعة مناطق لتجميع التدفقات وذات اتجاه من الجنوب

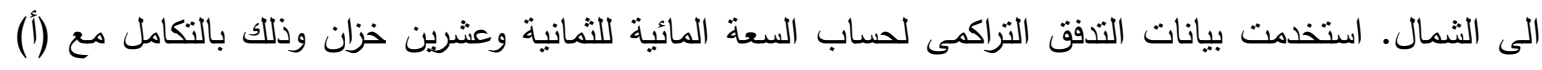
التدرج في الميل (ب) التتبؤ بمنوسط معدل هطول الامطار للمناخ المنوقع في الفترة من (2011 - 2030) و (ج) معامل الجريان السطحى. أظهرت النتائج ان منوسط حصاد الماء سيكون حده الأقصى (278828 م²/سنه) وحده الأدنى (18992

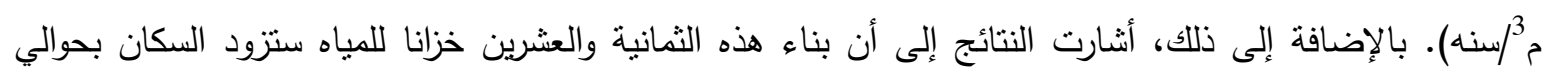
2604325 م³/ سنة (أكثر من مليوني م من الماء) عن كل سنة من الفترة المستقبلية (2011-2030). أظهرت النتائج المتوقعة للاحتياجات المائية للمحاصيل في الفترة المستقبلية (2011 - 2030) أن البرسيم الحجازى يحتاج لأكبر كمية من المياه (1275 مم/سنه) بينما يحتاج الشعير الى أقل كمية من المياه (247 مم/موسم) بالإضافة ان الاحتياج المائى للذرة السكرية والقمح ريما يكون 330 و 250 مم/ موسم بالترتيب.

Vol. 20(1), 2015 156 
الدمج بين الاحتياجات المائية المطلوبة مع كمية مياه الحصاد بالخزانات الهمعة استخدم لحساب المساحات

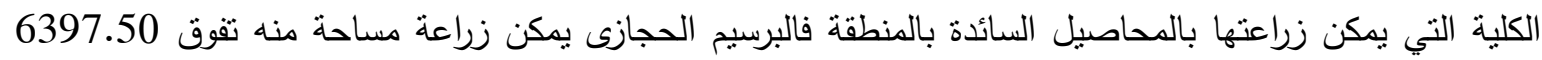

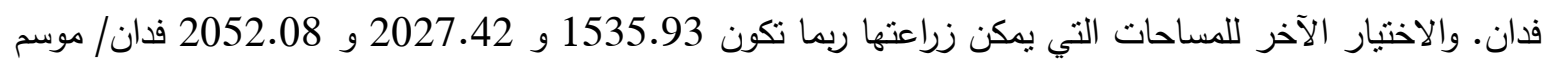

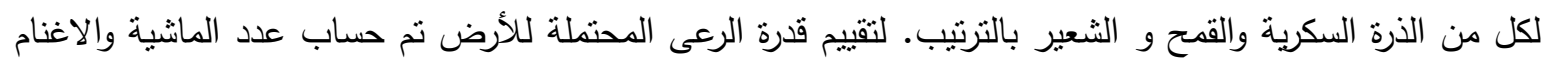

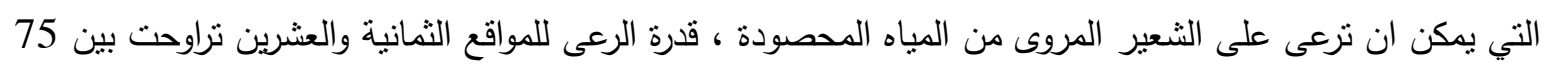

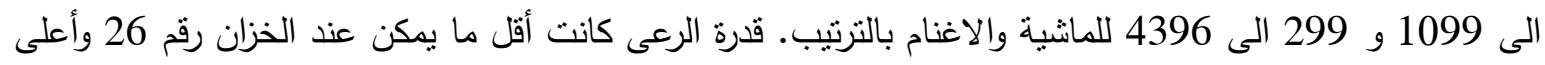

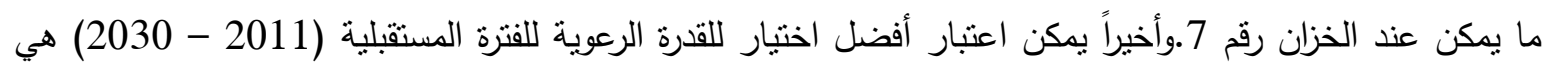
10264 للماشية و 41058 للأغنام. 